\title{
Clinical significance of the expression of connexin26 in colorectal cancer
}

\author{
Shinya Nomura, Kiyoshi Maeda, Eiji Noda*, Toru Inoue, Shinya Fukunaga, Hisashi Nagahara and Kosei Hirakawa
}

\begin{abstract}
Background: Connexin26 (Cx26) is one of the connexins (Cxs) family members which form gap junction channels. Cx26 is considered to be a tumor suppressor gene. However, recent studies revealed that over expression of Cx26 is associated with a poor prognosis in several human cancers. This study investigated the correlation between Cx26 expression and the clinicopathological features and P53 expression in colorectal cancer.

Methods: One hundred and fifty-three patients who underwent a curative resection were studied. Tissue samples were investigated by immunohistochemical staining using antibodies for Cx26 and P53. Moreover, apoptotic cells were detected by terminal deoxynucleotidyl transferase-mediated dUTP-biotin nick end-labeling (TUNEL) staining.

Results: Cx26 expression was found in 83 cases (54.2\%) and P53 expression in 71 cases (46.4\%). A correlation was observed between the $C x 26$ expression and recurrence, histology, and p53 expression $(P<0.05)$. Cx26 positive tumors had significantly longer survival than $C \times 26$ negative tumors $(P<0.05)$. A multivariate Cox analysis demonstrated that Cx26 expression was an independent prognostic factor $(P<0.05)$. However, no significant correlation was observed between Cx26 and Al.

Conclusion: This study suggests that Cx26 expression is an independent prognostic factor in patients that undergo a curative resection of colorectal cancer.
\end{abstract}

\section{Introduction}

A gap junction is a specialized intercellular connection that directly connects the cytoplasm of two cells, and allows various molecules and ions $(<1 \mathrm{kDa})$ to pass freely between cells. Gap junctional intercellular communication (GJIC) mediated by gap junctions play an important role in regulating homeostasis, proliferation and differentiation [1,2]. Gap junction channels contain two hemichannels that are primarily homo -or hetero-hexamers of connexin $(\mathrm{Cx})$ proteins [3]. Twenty types of $\mathrm{Cx}$ have been identified as transmembrane proteins [4]. A reduction or loss of GJIC function associated with human carcinomas such as skin cancer, lung cancer, gastric cancer, hepatocellular carcinoma, glioma and prostate cancer, is usually induced by down-regulation of Cxs [5-9]. Moreover, restoration of GIIC in tumor cell lines by $\mathrm{Cx}$ transfection can reduce growth and tumorigenicity $[10,11]$. Therefore, Cxs are thought to be tumor suppressor genes. However, over

* Correspondence: nodatch@med.osaka-cu.ac.jp

1 Department of Surgical Oncology, Osaka City University Graduate School of Medicine, 1-5-7 Asahimachi Abeno-ku, Osaka, 545-8585, Japan

Full list of author information is available at the end of the article expression of Cx26 might the acquisition of malignant phenotypes and is correlated with metastasis, tumor grade and prognosis in several carcinomas [12-14]. Therefore, this study examined the correlation between Cx26 expression by immunohistochemistry in colorectal carcinoma and clinicopathological features and P53 expression as a tumor suppressor gene.

\section{Materials and methods}

This study evaluated 153 patients with colorectal carcinoma who underwent a curative resection at the Department of Surgical Oncology (First Department of Surgery) of Osaka City University Graduate School of Medicine (Osaka, Japan). The age of the patients ranged 30 from 84 years (mean 65.5 years); and there were 87 males and 66 females were included. All of them underwent a curative resection and were followed for at least 5 years after surgery. Hematoxylin and eosin-stained slides were reviewed and the diagnoses were confirmed.

Tumor staging was defined according to the criteria for histological classification proposed by the International Union Against Cancer (UICC). Patients were informed of 
the investigational nature of the study and each provided written informed consent prior to recruitment.

Resected specimens from these patients were fixed in a $10 \%$ formaldehyde solution and embedded in paraffin. Four micrometer thick sections were cut and mounted on glass slides.

\section{Immunohistochemical method}

Cx26 and P53 immunostaining were performed by the streptavidin-biotin method. As primary antibodies, mouse monoclonal anti-Cx26 (Zymed Laboratories, San Francisco, CA, working dilution 1:500) and mouse monoclonal P53 antibodies (DAKO, Carpinteria, CA, ready to use) were used. The sections were cut $(4 \mu \mathrm{m})$, dried for 4 $h$ at $58^{\circ} \mathrm{C}$, and then dewaxed in xylene and dehydrated through an ethanol series. Endogenous peroxidase was blocked by incubation with $0.3 \% \mathrm{H} 2 \mathrm{O} 2$ in methanol for $30 \mathrm{~min}$ at room temperature. Thereafter, the sections were autoclaved for $10 \mathrm{~min}$ at $121^{\circ} \mathrm{C}$ in $10 \mathrm{mM}$ sodium citrate ( $\mathrm{pH}$ 6.0). The sections were washed with phosphate-buffered saline (PBS) and incubated with $10 \%$ normal rabbit serum for $10 \mathrm{~min}$ to reduce non-specific staining. The specimens were incubated with the respective primary antibodies in a moist chamber overnight at $4^{\circ} \mathrm{C}$. The specimens were washed with PBS and incubated in a secondary antibody for $10 \mathrm{~min}$ at room temperature. The sections were washed three times in PBS and incubated with the streptavidin-peroxidase reagent for $5 \mathrm{~min}$ at room temperature. Finally, the sections were incubated for $5 \mathrm{~min}$ in PBS containing diaminobenzidine and 1\% hydrogen peroxide (Histofine SAB-PO kit, Nichirei), followed by counterstaining with Mayer's hematoxylin. As the negative control, incubation with the primary antibody was omitted.

Moreover, we investigated the apoptotic cells by terminal deoxynucleotidyl transferase-mediated dUTP-biotin nick end-labeling (TUNEL) staining, using an In Situ Apoptosis Detection Kit (MK-500; Takara bio Co., Tokyo, Japan) according to the manufacturer's instructions.

\section{Staining Analysis}

Immunoreactivity for $\mathrm{Cx} 26$ was considered to be positive if distinct staining of the cytoplasm was observed in at least $10 \%$ of the tumor cells (Fig. 1) and P53 was considered to be positive if distinct staining of the nuclei was observed in at least $50 \%$ of tumor cells (Fig. 2). The apoptotic index (AI) was expressed as the number of apoptotic tumor cells divided by the total number of tumor cells in the same field with evaluation of 1000 nuclei in randomly selected areas in each specimen (Fig. 3).

The slides were examined by two independent pathologists who were not aware of the corresponding clinicopathological data. Any cases with discordant scores were reevaluated a second time until a consensus was reached,

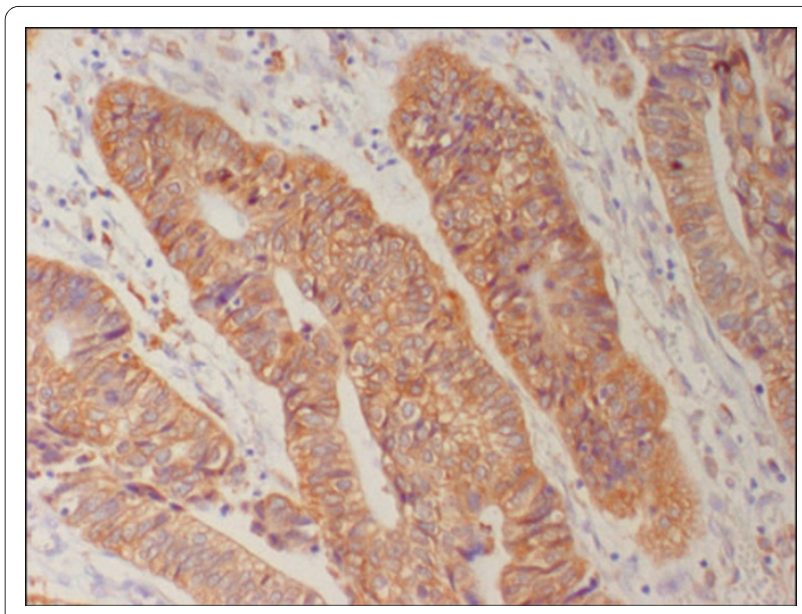

Figure 1 Immunohistochemical staing for $\mathrm{Cx} 26$ in colorectal cancer. Cytoplasmic Cx26 expression was found $(\times 200)$.

no discrepancies between the evaluations were detected by the two investigators.

\section{Statistical Analysis}

The data were compiled and analyzed using the SPSS software package for Windows (version 11.0; SPSS Inc., Chicago, Ill., USA). The relationship between Cx26 expression and the clinicopathological data, P53 and AI was evaluated by the chi-square test and Mann-Whitney $\mathrm{U}$ test. The disease specific survival was calculated by the Kaplan-Meier method and analyzed by the log-rank test. Prognostic factors were examined by univariate and multivariate analyses using a Cox proportional hazards model. $\mathrm{P}<0.05$ was considered to be significant.

\section{Results}

Cx26 expression was mainly localized in the cytoplasm of the cancer cells. In a few cases, we observed weak cyto-

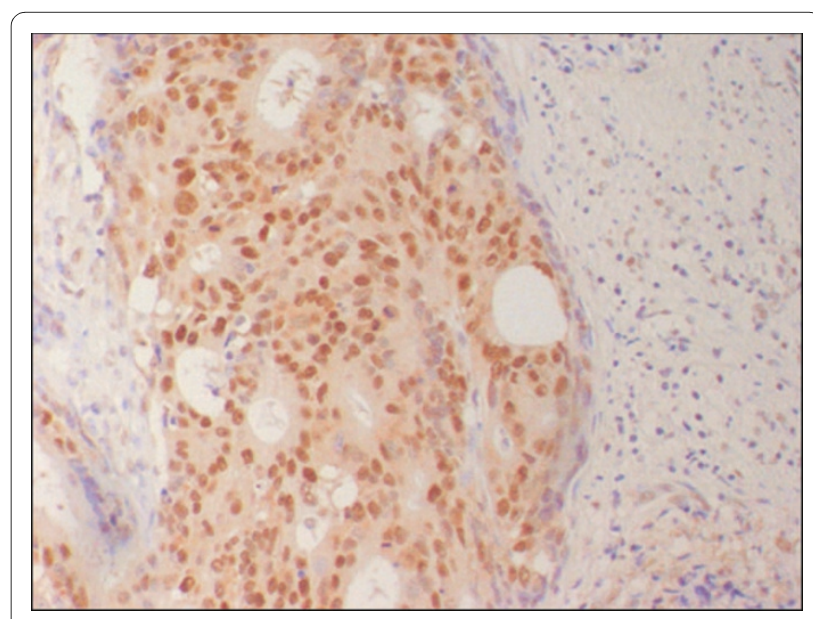

Figure $\mathbf{2}$ Immunohistochemical staing for P53 in colorectal cancer. Nuclear P53 expression was found in most tumor cells $(\times 200)$. 


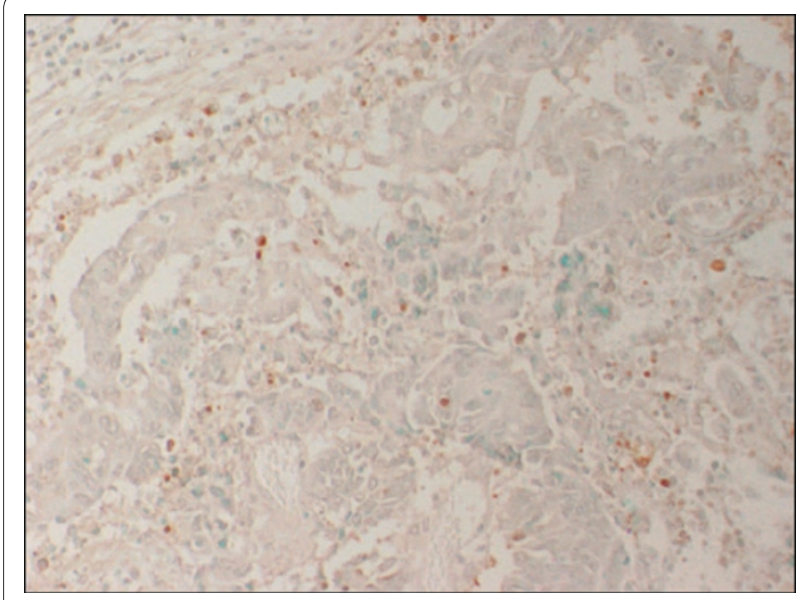

Figure 3 Apoptotic index (AI) as evaluated by TUNEL $(\times 200)$. plasmic staining in the normal mucosa. However we did not consider this to be specific staining. Eighty-three of the 153 tumors (54.2\%) showed Cx26 expression. P53 expression was observed in 71 (46.4\%). The correlation between $\mathrm{Cx} 26$ and the clinicopathological features is summarized in Table 1. Cx26 expression had a statistically significant relationship with disease recurrence and the histological type $(\mathrm{P}<0.05)$. Moreover $\mathrm{P} 53$ expression had a statistically significant relationship with Cx26 expression $(\mathrm{P}<0.05)$. The disease specific survival according to the status of $\mathrm{Cx} 26$ expression is shown in Fig.4. The patients with Cx26 negative tumors had significantly worse survival than those with positive tumors ( $\mathrm{P}$ $<0.05)$. Cx26 expression was an independent prognostic factor, as well as lymph node metastasis, blood vessels invasion according to a multivariate analysis (Table 2).

Table 1: Correlation between the Cx26 expression and clinicopathological features

\begin{tabular}{|c|c|c|c|}
\hline \multicolumn{4}{|c|}{ Cx26 } \\
\hline & Negative & Positive & P-value \\
\hline Age (mean $\pm S D$, years. & $66.4 \pm 8.1$ & $66.4 \pm 10.5$ & \\
\hline \multicolumn{4}{|l|}{ Gender } \\
\hline Male & 41 & 46 & \\
\hline Female & 29 & 37 & 0.695 \\
\hline Tumor size (mean $\pm \mathrm{SD}, \mathrm{cm}$. & $5.0 \pm 2.1$ & $5.1 \pm 2.9$ & \\
\hline \multicolumn{4}{|l|}{ Lymphatic invasion } \\
\hline Negative & 24 & 25 & \\
\hline Positive & 46 & 58 & 0.582 \\
\hline \multicolumn{4}{|l|}{ Blood vessel invasion } \\
\hline Negative & 60 & 68 & \\
\hline Positive & 10 & 15 & 0.528 \\
\hline \multicolumn{4}{|l|}{ Lymph node metastasis } \\
\hline Negative & 47 & 53 & \\
\hline Positive & 23 & 30 & 0.670 \\
\hline \multicolumn{4}{|l|}{ Site } \\
\hline Colon & 47 & 60 & \\
\hline Rectum & 23 & 23 & 0.489 \\
\hline \multicolumn{4}{|l|}{ Depth of invasion } \\
\hline$\sim \mathrm{mp}$ & 17 & 11 & \\
\hline$\sim \mathrm{ss}$ & 53 & 72 & 0.079 \\
\hline \multicolumn{4}{|l|}{ Disease recurrence } \\
\hline Negative & 44 & 65 & \\
\hline Positive & 26 & 18 & 0.035 \\
\hline \multicolumn{4}{|l|}{ Histological type } \\
\hline Well & 22 & 27 & \\
\hline Moderately & 37 & 55 & \\
\hline Others & 11 & 1 & 0.003 \\
\hline \multicolumn{4}{|l|}{ P53 } \\
\hline Negative & 31 & 51 & \\
\hline Positive & 39 & 32 & 0.034 \\
\hline
\end{tabular}




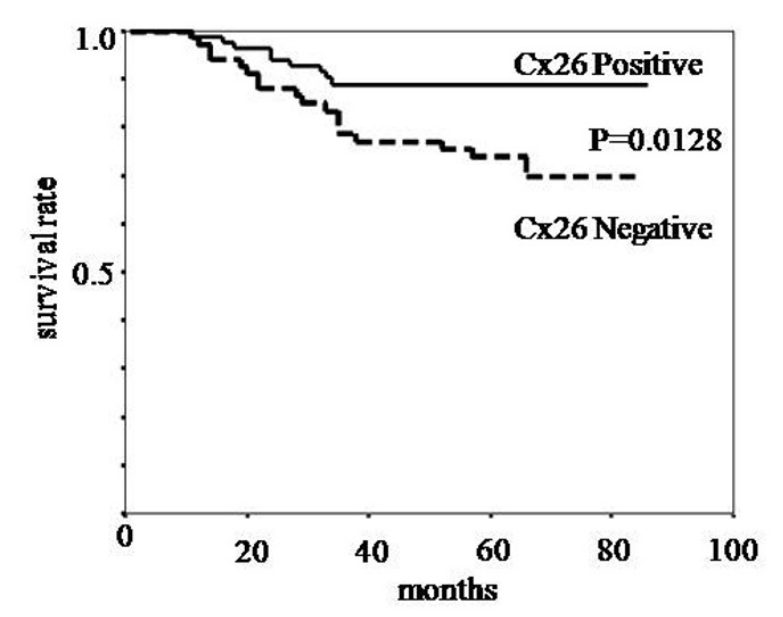

Figure 4 The disease specific survival according to $C \times 26$ expression. Patients with $\mathrm{C} \times 26$ positive tumors showed significantly longer survival than those with $C \times 26$ negative tumors $(P=0.0128)$

There was no significant correlation between Cx26 and AI (Fig. 5).

\section{Discussion}

Several studies of colorectal carcinoma reported that Cx26 expression is found mainly in the plasma membrane in normal epithelium and malignant transformation is associated with the loss of plasma membrane staining and increased cytoplasmic staining [15-18]. However, Knösel et al. also reported the Cx26 expression to be observed in the cytoplasm of colon cancer cells, while it was not observed in the normal mucosa [19]. Our current data showed the same results. The Cx26 expression was observed in the cytoplasm in $54.2 \%$ of the col-

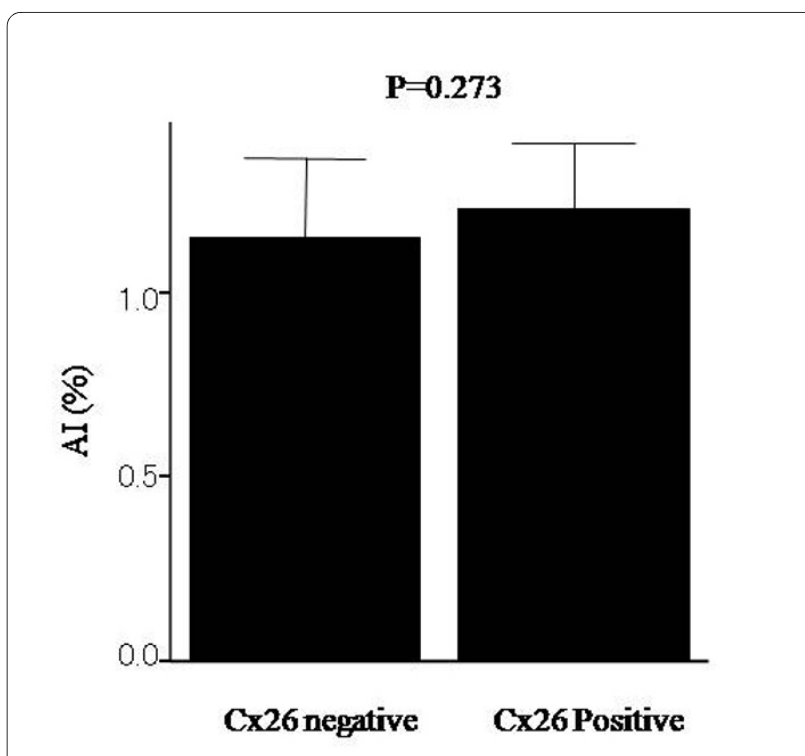

Figure 5 Value of apoptotic index (AI) according to Cx26 expression. No significant correlation was found $(P=0.273)$

orectal tumors in the current series. Although, the mechanism of cytoplasmic staining was unclear, we therefore assumed the cytoplasmic staining of $\mathrm{Cx} 26$ to be independent from the GIC- mechanism in colon cancer. Several studies reported that Cx26 expression is associated with poor prognosis in lung and esophageal squamous cell carcinoma and breast cancer $[13,14,20]$. However Knösel et al. [19] reported that reduced Cx26 expression is significantly associated with shorter patients' survival and higher tumor grade. The current study also found that patients with Cx26 negative tumors had worse survival than those with Cx26 positive tumors.

Table 2: Univariate and multivariate survival analyses of the prognostic factors

\begin{tabular}{|c|c|c|c|c|}
\hline \multicolumn{5}{|l|}{ Multivariate analysis } \\
\hline Variable & Comparsiion & Hazard ratio & P-value & $95 \% \mathrm{Cl}$ \\
\hline $\mathrm{C} \times 26$ & Negative : Positive & 3.734 & 0.002 & $1.607-8.674$ \\
\hline $\begin{array}{l}\text { Lymph node } \\
\text { metastasis }\end{array}$ & Positive : Negative & 2.587 & 0.027 & $1.115-5.999$ \\
\hline Lymphatic invasion & Positive : Negative & 2.584 & 0.139 & $0.735-9.083$ \\
\hline Vessel invasion & Positive : Negative & 4.084 & 0.002 & $1.687-9.887$ \\
\hline Tumor size & $>5 \mathrm{~cm}: \% 5 \mathrm{~cm}$ & 2.658 & 0.065 & $0.941-7.507$ \\
\hline \multicolumn{5}{|l|}{ Univariate analysis } \\
\hline $\mathrm{C} \times 26$ & Negative : Positive & 2.651 & 0.017 & $1.191-5.903$ \\
\hline $\begin{array}{l}\text { Lymph node } \\
\text { metastasis }\end{array}$ & Positive : Negative & 4.720 & $<0.001$ & $2.118-10.516$ \\
\hline Lymphatic invasion & Positive : Negative & 4.387 & 0.016 & $1.320-14.580$ \\
\hline Vessel invasion & Positive : Negative & 4.044 & $<0.001$ & $1.844-8.870$ \\
\hline Tumor size & $>5 \mathrm{~cm}: \% 5 \mathrm{~cm}$ & 3.961 & 0.005 & $1.500-10.462$ \\
\hline
\end{tabular}


Moreover, the multivariate analysis showed that Cx26 was an independent prognostic factor.

Cx26 is thought to be a tumor suppressor gene, but mechanism which regulates tumor suppression is unclear. Several studies have reported suggestive evidence that the tumor-suppressive effects of Cx expression are GJIC-independent [10,21]. Cytoplasmic staining of Cx26 was considered to be a GJIC-independent mechanism. Cx26 may have an effect on other tumor related genes. Hong et al. reported a significant correlation between the Cx26 expression and P53 expression [17]. P53 is a common tumor suppressor gene and plays a major role in regulating the cell cycle and apoptosis [22]. The expression of P53 in colorectal cancer is thought to be associated with poor prognosis [23-25]. A mutation of the P53 is frequently observed in several human tumors. The expression of P53 protein is equivalent to the presence of a mutation of the p53 gene [26]. Therefore, we investigated the relationship between Cx26 and P53 protein. Cx26 expression had an inverse correlation with P53 expression. Cx26 positive tumors tended to have negative P53 expression.

On the other hand, p53 gene regulates apoptosis and P53 positive tumors show decreased AI [27]. Therefore, the relationship between Cx26 and AI was investigated. However, there was no significant relationship between Cx26 and AI.

In conclusion, the Cx26 function in cancer cells is unclear. Cx26 expression was an independent prognostic factor in colorectal cancer in the current series. Therefore, an analysis of the Cx26 expression may be useful for selecting patients who are at high risk for recurrence.

\section{Competing interests}

The authors declare that they have no competing interests.

\section{Authors' contributions}

EN and KM contributed to the conception and design of the study; SN, EN and $\mathrm{KM}$ contributed to collection and assembly of data; $\mathrm{SN}, \mathrm{EN}, \mathrm{KM}, \mathrm{Tl}, \mathrm{SF}, \mathrm{HN}$ and $\mathrm{KH}$ contributed to data analysis and interpretation; $\mathrm{SN}, \mathrm{KM}$, EN contributed to manuscript writing. All authors have read and approved the final manuscript.

\section{Author Details}

Department of Surgical Oncology, Osaka City University Graduate School of Medicine, 1-5-7 Asahimachi Abeno-ku, Osaka, 545-8585, Japan

Received: 31 March 2010 Accepted: 21 June 2010

Published: 21 June 2010

\section{References}

1. Kumar NM, Gilula NB: The gap junction communication channel. Cell 1996, 84:381-388.

2. Charles AC, Naus CC, Zhu D, Kidder GM, Dirksen ER, Sanderson MJ: Intercellular calcium signaling via gap junctions in glioma cells. J Cell Biol 1992, 118:195-201.

3. Willecke K, Eiberger J, Degen J, Eckardt D, Romualdi A, Guldenagel M, Deutsch U, Sohl G: Structural and functional diversity of connexin genes in the mouse and human genome. Biol Chem 2002, 383:725-737.

4. Sohl G, Willecke K: Gap junctions and the connexin protein family. Cardiovasc Res 2004, 62:228-232.
5. Kamibayashi Y, Oyamada Y, Mori M, Oyamada M: Aberrant expression of gap junction proteins (connexins) is associated with tumor progression during multistage mouse skin carcinogenesis in vivo. Carcinogenesis 1995, 16:1287-1297.

6. Jinn Y, Ichioka M, Marumo F: Expression of connexin32 and connexin43 gap junction proteins and E-cadherin in human lung cancer. Cancer Lett 1998, 127:161-169.

7. Mourelle M, Casellas F, Guarner F, Salas A, Riveros-Moreno V, Moncada S, Malagelada JR: Induction of nitric oxide synthase in colonic smooth muscle from patients with toxic megacolon. Gastroenterology 1995, 109:1497-1502.

8. Krutovskikh V, Mazzoleni G, Mironov N, Omori Y, Aguelon AM, Mesnil M, Berger F, Partensky C, Yamasaki H: Altered homologous and heterologous gap-junctional intercellular communication in primary human liver tumors associated with aberrant protein localization but not gene mutation of connexin 32. Int J Cancer 1994, 56:87-94.

9. Tsai H, Werber J, Davia MO, Edelman M, Tanaka KE, Melman A, Christ GJ, Geliebter J: Reduced connexin 43 expression in high grade, human prostatic adenocarcinoma cells. Biochem Biophys Res Commun 1996, 227:64-69.

10. Lee HJ, Lee IK, Seul KH, Rhee SK: Growth inhibition by connexin26 expression in cultured rodent tumor cells. Mol Cells 2002, 14:136-142.

11. Momiyama M, Omori Y, Ishizaki Y, Nishikawa Y, Tokairin T, Ogawa J, Enomoto K: Connexin26-mediated gap junctional communication reverses the malignant phenotype of MCF-7 breast cancer cells. Cancer Sci 2003, 94:501-507.

12. Ito A, Katoh F, Kataoka TR, Okada M, Tsubota N, Asada H, Yoshikawa K, Maeda S, Kitamura Y, Yamasaki H, Nojima H: A role for heterologous gap junctions between melanoma and endothelial cells in metastasis. J Clin Invest 2000, 105:1189-1197.

13. Ito A, Koma Y, Uchino K, Okada T, Ohbayashi C, Tsubota N, Okada M: Increased expression of connexin 26 in the invasive component of lung squamous cell carcinoma: significant correlation with poor prognosis. Cancer Lett 2006, 234:239-248.

14. Naoi Y, Miyoshi Y, Taguchi T, Kim SJ, Arai T, Tamaki Y, Noguchi S: Connexin26 expression is associated with lymphatic vessel invasion and poor prognosis in human breast cancer. Breast Cancer Res Treat 2007, 106:11-17.

15. Kanczuga-Koda L, Sulkowski S, Koda M, Skrzydlewska E, Sulkowska M: Connexin 26 correlates with $\mathrm{Bcl}-\mathrm{xL}$ and Bax proteins expression in colorectal cancer. World J Gastroenterol 2005, 11:1544-1548.

16. Kanczuga-Koda L, Sulkowski S, Koda M, Sulkowska M: Alterations in connexin26 expression during colorectal carcinogenesis. Oncology 2005, 68:217-222.

17. Hong R, Lim SC: Pathological significance of connexin 26 expression in colorectal adenocarcinoma. Oncol Rep 2008, 19:913-919.

18. Ezumi K, Yamamoto H, Murata K, Higashiyama M, Damdinsuren B, Nakamura Y, Kyo N, Okami J, Ngan CY, Takemasa I, et al: Aberrant expression of connexin 26 is associated with lung metastasis of colorectal cancer. Clin Cancer Res 2008, 14:677-684.

19. Knosel T, Emde A, Schluns K, Chen Y, Jurchott K, Krause M, Dietel M, Petersen I: Immunoprofiles of 11 biomarkers using tissue microarrays identify prognostic subgroups in colorectal cancer. Neoplasia 2005, 7:741-747.

20. Inose T, Kato H, Kimura H, Faried A, Tanaka N, Sakai M, Sano A, Sohda M, Nakajima M, Fukai Y, et al: Correlation between connexin 26 expression and poor prognosis of esophageal squamous cell carcinoma. Ann Surg Oncol 2009, 16:1704-1710.

21. McLachlan E, Shao Q, Wang HL, Langlois S, Laird DW: Connexins act as tumor suppressors in three-dimensional mammary cell organoids by regulating differentiation and angiogenesis. Cancer Res 2006, 66:9886-9894

22. Lane DP: Cancer. p53, guardian of the genome. Nature 1992, 358:15-16.

23. Hamelin R, Laurent-Puig P, Olschwang S, Jego N, Asselain B, Remvikos Y, Girodet J, Salmon RJ, Thomas G: Association of p53 mutations with short survival in colorectal cancer. Gastroenterology 1994, 106:42-48.

24. Houbiers JG, van der Burg SH, van de Watering LM, Tollenaar RA, Brand A, van de Velde CJ, Melief CJ: Antibodies against p53 are associated with poor prognosis of colorectal cancer. Br J Cancer 1995, 72:637-641.

25. Goh HS, Yao J, Smith DR: p53 point mutation and survival in colorectal cancer patients. Cancer Res 1995, 55:5217-5221. 
26. Chilosi M, Doglioni C, Magalini A, Inghirami G, Krampera M, Nadali G, Rahal D, Pedron S, Benedetti A, Scardoni M, et al.: p21/WAF1 cyclin-kinase inhibitor expression in non-Hodgkin's lymphomas: a potential marker of p53 tumor-suppressor gene function. Blood 1996, 88:4012-4020.

27. Shibata $\mathrm{H}$, Matsubara O: Apoptosis as an independent prognostic indicator in squamous cell carcinoma of the esophagus. Pathol Int 2001, 51:498-503.

doi: $10.1186 / 1756-9966-29-79$

Cite this article as: Nomura et al., Clinical significance of the expression of connexin26 in colorectal cancer Journal of Experimental \& Clinical Cancer Research 2010, 29:79

Submit your next manuscript to BioMed Central and take full advantage of:

- Convenient online submission

- Thorough peer review

- No space constraints or color figure charges

- Immediate publication on acceptance

- Inclusion in PubMed, CAS, Scopus and Google Scholar

- Research which is freely available for redistribution

Submit your manuscript at www.biomedcentral.com/submit 